\title{
DYNASTIC BLUFF? THE ROAD TO MIELNIK, 1385-1501
}

\section{S. C. ROWELL}

ABSTRACT This article views the act of Union issued at Mielnik in 1501 in the longue durée of Lithuano-Polish relations from 1385/86. It stresses the need to treat the dynastic aims of Jogaila and his son Casimir seriously, regarding the thrones of Lithuania and Poland within the context of developments in family law and inheritance in the Grand Duchy and the Kingdom in the fifteenth century. Textual echoes are noted between a 'union' agreement outlined ca. 1453 and the Mielnik document.

Historical scholarship requires its practitioners balance an appreciation of the wide panorama of events with attention to detail without obsessive pedantry. The Act maintaining the Union between the Grand Duchy of Lithuania and the Kingdom of Poland which was agreed at Mielnik in October 1501 but never ratified by the Lithuanian nobility en masse, and which in the course of events remained unimplemented in all its detail, is a topic that requires such balance. It presents us with a microcosm of conflicting flurries of PolishLithuanian political tactics and legal thought at the end of the fifteenth century. The debates provoked by the succession after the death of Casimir I and IV in 1492 and that of his son and heir in Poland, John Albert, in 1501 themselves reveal the understanding of the Polish-Lithuanian state in the eyes of its primary creators, the Jagiellonian family. However, the fluctuations in Jagiellonian power, thought and ambitions defy a historian's attempts to form a tranquil model from the convulsions of the Past, where almost every succession was decided on its own particular merits rather than in strict accordance with written treaties. One can trace developments in the relationship between these two nations backwards from 1569 or even from 1795 to 1385 and see a rational growth in a whole series of beautifully sounding but actually not fully implemented agreements. Yet the union survived, and strict criticism of individual documents cannot deny the sustained existence of a common bond. Understanding the Union is made more complex still 
by the fact that neither part of the Jagiellonian domain was monolithic in its political philosophy, especially in the fifteenth century. The political elites of the Kingdom of Poland were divided over the relative positions of the nobility and the king in the polity, especially in connection with the succession to the throne, which the Jagiellonian kings regarded as their inheritance and the Malopolskan nobility as its right to bestow. What the Malopolskan nobility wanted most out of Lithuania was not land (the lands disputed with the Grand Duchy were not the original territory of either side, but Rus'ian regions desired and disputed by both parties since c. 1323) but a potential alliance of interests against the joint monarch - as was the case with Bishop Oleśnicki of Cracow's support for Prince Mykolas Žygimantaitis in the late 1440s and perhaps by implication in his 1445 letter to Bishop Matthew of Vilnius, even though the latter and his associates were unbeguiled by the offer, if indeed they understood it. ${ }^{1}$ The Jagiellonian Lithuanian patrimony was also a field of dispute between various members of the ruling house and diverse scions of the nobility who were jealous for their own position in the state, as is evident from Catholic attempts to block the political rise of the Orthodox and Unionist boiarate. The Lithuanian nobility as a governing class became actively involved as a player, rather than an observer or granter of approval, in union treaties only in the last decade of the fifteenth century. In this brief view of the dynastic assessment of the Lithuano-Polish confederation we will look at three aspects of the Union leading up to Mielnik: firstly at Lithuania as the patrimony of the Jagiellonians as dukes-proprietors (to borrow a Castilian word) and developments in property inheritance rights in the Grand Duchy over the fifteenth century; secondly, at Poland as the potential patrimony of the Jagiellonians and the conflict between a strong Crown and strong Estates with regard to election to the Polish throne; and thirdly, at the Jagiellonian policy of bluff in maintaining the family's position in both states, especially in the run up to Mielnik. We shall conclude with a survey of Mielnik's place in Jagiellonian Union tradition.

Jogaila's Lithuanian Patrimony 'The kings of Hungary and Poland have dominions which are not patrimonies but were gained through

${ }^{1}$ Codex epistolaris saeculi decimi quinti [CESXV] I.2, ed. J. Szujski Nr. 5, p. 10-11 - undated letter datable to period before August 1445; on Mykolas and Oleśnicki, see below, p. 4, 8 . 
good fortune and election, ..., but your Illustriousness holds the property of your [and their] father and grandfather', or so a noble embassy sought to convince Grand Duke Alexander in $1496 .^{2}$ That the Grand Duchy of Lithuania was regarded as the patrimonial property of its ruling dynasty is the generally accepted view and there is no doubt that it is correct. Almost like any piece of Lithuanian land it was family property and in times of peace, domestic and foreign, control of it could be inherited by male family members, with the man perceived most fitting by his predecessor and/ or siblings to be grand duke being granted that role. The principle of designation rather than primogeniture decided who should rule Lithuania. Thus, it could be argued, Jaunutis was selected to succeed Gediminas most likely as a compromise between two fraternal alliance groups. He was removed by one such alliance when he proved unable to govern sufficiently well. The duo which ousted Jaunutis from power, Grand Duke Algirdas and his ally, Prince Kęstutis, subsequently gained general acceptance with Algirdas becoming the senior, or grand duke among the other princes of the blood. ${ }^{3}$ Despite attempts from collateral branches of the AlgirdanGediminid line, especially the Kestutids, to seize power from Algirdas' sons, it seems that the line of the prince who became grand duke tended to neutralise the claims of other brothers, cousins and uncles who gained duchies within or, preferably, without the Grand Duchy. Jogaila succeeded in doing this by accident. His powerful rival, to whom he had to surrender the grand ducal throne, Vytautas, died without male issue, leaving as rivals for Jogaila Vytautas' brother, the eventually unpopular Žygimantas, and Jogaila's own brother Švitrigaila, who had also been unsuccessful in his attempts to become grand duke. After Jogaila had absented himself from the country following his election to the Polish throne, the brother whom he left behind to administer the Grand Duchy, Skirgaila, failed to win and maintain wide support in Lithuania and by 1392 a compromise between Jogaila and Vytautas had been unavoidable. Nevertheless, by the time Jogaila died the Vilnius faction of the Lithuanian nobility led by Goštautas (Gasztold) and the Alšèniškiai (Holszański)

${ }^{2}$ Akty, otnosiashchiesia k istorii Zapadnoi Rusi [AZR], ed. I. Grigorovich, I (St Petersburg, 1846), No.135 §6, p. 161.

${ }^{3}$ S. C. Rowell, Lithuania Ascending. A pagan empire in east-central Europe 1295-1345 (Cambridge, 1994), 280-87. 
dukes was prepared to keep their word, given before Vytautas' death, to accept Jogaila's sons as grand duke. ${ }^{4}$

The extension of family law to the political arena was a useful tool for maintaining power in a period of almost continuous warfare, expansion and internal dispute (during the thirteenth and fourteenth centuries) and it served the Gediminid family well. However, after the introduction of Christianity as a 'state' religion in the late fourteenth century, domestic disputes gradually dominated over foreign wars (with Poland or the Teutonic Order) and aggressive expansion (into Rus'). A compromise was effected by Jogaila with his cousin Vytautas. The latter began a policy of curbing the power of his kinsmen princes within the Grand Duchy, seeking to further undermine the claims to land and power of other Gediminid princes. He failed to produce a suitable heir to his body. Jogaila and his sons sought to 'regain' 'lost' lands from their kin, especially the Kestutids, but also other Gediminids and scions of Algirdas - the most notorious examples being Švitrigaila, who had succeeded, after losing his fight for the throne, in carving himself out a domain in Volyn', and Mykolas Žygimantaitis, whose attempts at retrieving his grandfather's patrimony were resisted vigorously by Casimir and pressed further still and without success by Mykolas' widow. ${ }^{5}$ In 1501 Casimir's eldest son, King Władysław of Hungary and Bohemia, stressed that although he and his brothers may not be regales in Poland, they are, nonetheless, all dukes in Lithuania. The sons of Jogaila stressed their hereditary rights in Lithuania and attempted to do likewise in Poland. The Union of Horodło (1413) further strengthened this position, at least in the eyes of Jogaila and his heirs who used talk of incorporation for their own ends (see below). One of the least often aired theories connected with the Vytautan coronation fiasco is that offered by L. Kolankowski, asserting that the plan was dreamed up by Jogaila, not his cousin. If this interpretation is not based on Dlugoszian anti-propaganda or misunderstanding on the part of the Teutonic Order's spies, it seems quite Jagiellonian in its almost crazed obsession with hereditary royal status. Even if

${ }^{4}$ After Žygimantas Kęstutaitis was murdered, the Jagiellonian line regained the throne and retained it in spite of considerable armed resistance to its rule in Žemaitija and certain Rus'ian principalities.

5 On Mykolas, see A. Kopystiański, 'Ksiązę Michał Zygmuntowicz', Kwartalnik Historyczny 20 (1906), 74-165; Catherine's resort to papal assistance to gain her dead husband's patrimony: CEXV I.1, No. 196 
the author of the plan were, after all, as contemporary commentators wrote, Emperor Sigismund, or Vytautas himself, Jogaila's last minute attempt at damage limitation in September 1430 is at heart dynastic, an attempt to ensure that the 'kingship' of Lithuania will not be separated from the grand-ducal patrimony as a whole and that it will be bequeathed by Vytautas to Jogaila's son (thereby strengthening further that prince's position in Poland as the heir of two crowns, one of which he undeniably had been born to rule). ${ }^{6}$

The Jagiellonian political patrimony cannot be discussed without reference to general Lithuanian inheritance strategies in private life. Land was held in Lithuania by the family in the non-nuclear sense. Land could be controlled by a particular line or person without fully removing the right of other members of the stirps et genealogia to a voice in the disposition of that common inheritance. Thus, when the actual controllers of clan land such as Žygimantas, son of Michal Goliginowicz, donated ancestral land to his newly founded parish church in Didžioji Vaverka, he did so communiter with his distant kin. ${ }^{7}$ There seems to be a certain hierarchy within the clan

${ }^{6}$ Polnoe Sobranie Russkikh Letopisei XVII (St Petersburg, 1907), p. 525; Codex Epistolaris Vitoldi magni ducis Lithuaniae 1376-1430, [CRV] ed. A. Prochaska (Cracow, 1882) No. 1453; Długosz, Historia IV; L. Kolankowski, 'Jagiellonowie i Unja', Pamietnik VI Powszechnego zjazdu historyków polskich w Wilnie, 17-20 września 1935 r., II: Protokoty (Lwów, 1936), 279. This is a repeat of his 1928 article in Ateneum Wileńskie. For a summary of writing on the 'coronation storm' and a modern interpretation, see G. Błaszczyk, Burza koronacyjna. Dramatyczny fragment stosunków polsko-litewskich w XV wieku (Poznań, 1998), esp. pp. 1920. J. Nikodem also disagrees with attributing the plan to Jogaila - Idem, 'Spory o koronację wielkiego księcia Litwy Witolda w latach 1428-1430. Częśc II: Próba rekonstrukcji wydarzeń', Lituano-Slavica Posnaniensia. Studia Historica vii (1995), 164-66. It is unclear which crown Jogaila is offering, that of Poland or a new one of Lithuania. His action, especially in September 1430 (CEV 1453), if the Order's reporter understood rumours correctly, seems to be a damage limitation exercise with dynastic overtones. The use of a 'Lithuanian crown' to strengthen the dynasty's position in Poland (as well as in Lithuania) is apparent from the 1526 plans of Sigismund's illegitimate son, Jan de ducibus, and Jerzy Radziwill (Jurgis Radvila) to gain royal status for Lithuania - A. Swiezawski, 'Jan z ksiąząt litewskich', Polski stownik biografyczny X (Wrocław-Warsaw-Cracow, 1962-64), 440.

${ }^{7}$ Kodeks dyplomatyczny katedry i diecezji wileńskiej [KDKDW], ed. J. Fijałek, W. Semkowicz (Cracow, 1948) No. 247, pp. 282-6, discussed in R. Petrauskas, 'XV amžiaus Lietuvos bajorijos struktūra: giminès problema', Tarp istorijos ir būtoves. Studijos prof. Edvardo Gudavičiaus 70-mečiui, ed. A. Bumblauskas, R. Petrauskas (Vilnius, 1999), 128. 
but, R. Petrauskas notes, this is not directly apparent in the text itself. The same could be said of the ruling dynasty and its relationship with the political patrimony. Petrauskas shows how surnames came to be adopted, how coats of arms when granted to one part of the clan were available to other clan members. This seems to be compensation for being cut off from control of the original patrimony. We recall how the Czartoryski princes were granted rights to use the Gediminid vytis/pogon blazon after the semi-failed coup of $1440 .^{8}$ Rights to active involvement in the transfer of patrimonial land appears to have been restricted to three generations with a common grandfather. Petrauskas suggests this with reference to the Jagiellonian and Vytautan consideration of grandducal history from the death of Gediminas in the first and second redactions of the Lithuanian Chronicle. ${ }^{9}$ Similar thoughts arise when we read Casimir's curious reference to his grandfather Algirdas' charter for Vilnius which is otherwise unknown and which Casimir himself never mentions again: 'iuxta consuetudinem antiquam a nostris predecessoribus, et signanter serenissimis principibus avo videlicet Olgerdo olim magno duce Lithwanie et domino Wladislao Rege Polonie, tunc eciam magno duce existente genitore nostris'. ${ }^{10}$

Władysław of Hungary-Bohemia's comments on the difference between Poland, Hungary and Lithuania, which have already been noted, are similar. Bardach deduces from cases recorded in the Lithuanian Metrica that, as far as the niedzial, or impartible inheritance goes, 'przy zbyciu występuje rodzina zlozona z trzech pokolen dziadka, ojców i dzieci'. As with Casimir's case, claims to inheritance spread at most over three direct generations under normal circumstances. We also note that this system foresaw the existence of an elder brother to control the property. This 'starszy brat' was 'elder' by election or designation and not necessarily by age. ${ }^{11}$ In 1496 during debates over 'królewicz' Sigismund's inheritance, the

${ }^{8}$ The right of all sons of the Lithuanian ruling dynasty to style themselves 'prince' or duke (and even in Latin and German translation rex / könig, that is, 'king', without meaning 'the king' or monarch in the western European sense) is another reflection of the joint patrimony.

${ }^{9}$ Petrauskas, 'XV amžiaus', 130-31.

${ }^{10}$ Nov. 18 1440, Trakai: Zbiór praw polskich, p. 5. Modern readers might think reference to Gediminas would be of greater relevance.

11 J. Bardach, 'Niedzial w statutach litewskich na tle praktyki', [idem], Studia $z$ ustroju i prawa Wielkiego Księstwa Litewskiego XIV-XVII w. (Warsaw, 1970), $131,151-52$. 
Queen Mother, King John Albert and Cardinal Frederick asserted that Sigismund was willing to defer to Alexander 'iako bratu starshomu'. ${ }^{12}$ Grand-ducal office was clearly not open to any member of the dynasty. It is clear that in time collateral branches either lost or were forced to abandon any such right, as we see from the fates of Gediminids outside the Algirdan-Kestutid line and subsequently outside the Jagiellonian line. Those who challenged Casimir's rule in the 1440s (Mykolas Žygimantaitis), 1450s (Radvila - a rank outsider par excellence - and Olelkaitis) were not acceptable to the majority of the Grand Duchy's noble estate despite their dynastic credentials, or in Radvila's case, lack of them. ${ }^{13}$ The defection of Gediminid dukes to Muscovy in the late fifteenth century may have been influenced to some small degree by the decline of their significance for deciding the fate of the great patrimony. ${ }^{14}$

The fifteenth century seems to have witnessed a gradual change in hereditary practice, as we should expect from a society which officially has converted its 'basic customary law' (that is, its religion) to a new all-embracing system and is living under slightly different circumstances - multiple heredity which is so useful in a society at constant war does not fit life when the number of heirs is not so conveniently trimmable by violence.

One aspect of changes in views of inheritance is the niedzial ('impartibility'), or clan ownership of land which cannot be subdivided. In the mid-fifteenth century there are developments in inheritance practice away from simple niedziat to restrictions on disposition of a third of clan land, the trzecizna (or 'third part') and direct inheritance in one line. Juliusz Bardach detects a change in impartible inheritance around in the fifth decade of the fifteenth century, citing a donation of land by Casimir to Miszka Westortowicz which the recipient is not compelled to share with his brothers. ${ }^{15}$

12 AZR I, No. 135 part iv, p. 159. Alexander was Sigismund's senior in age, but the other Casimirids' junior (except for Frederick).

13 Attempts at overthrowing Casimir: S.C. Rowell, 'Bears and traitors, or: Political tensions in the Grand Duchy ca. 1440-1481', Lithuanian Historical Studies, 2 (1997), 28-55.

${ }^{14}$ O. P. Backus, Motives of west Russian nobles in deserting Lithuania for Moscow 1377-1514 (Lawrence, KA, 1957) uses the term 'centralization'. Centralization as such was typical too of Muscovy to which these dukes defected; in Lithuania the process involved disinheritance from the greater Gediminid patrimony.

${ }^{15}$ Bardach, 'Niedział', 168-9. 
He dates the introduction of trzecizna to the fifteenth century and traces it to Polish influence rather than Byzantine practice. ${ }^{16}$ Whether or not the Lithuanian practice was adopted from Poland or not (the practicality of the method is probably so fundamental to a move from impartible to partible inheritance, that we should be surprised if it did not develop in Lithuania without direct foreign influence), the fact seems to be that it is emerges at the same time as the political inheritance becomes limited. In Poland at this time trzecizna still existed, according to Bardach, but the tendency to primogeniture seems to have been threatening to prevail, judging by Casimir's Piotrków Ustawy of 1447, which seek to prevent elder brothers from appropriating the whole of the 'gymyenye dzyedzyczne', or references to Jogaila's first-born, Wladyslaw, who 'ut primogenitus in regem Polonie assumitur'. ${ }^{17}$ Around the same time Casimir is fiercely berated by Oleśnicki for denying his cousin Mykolas Žygimantaitis his patrimony. Casimir's aim was to remove a potential rival for power (as he had neutralised potential threats from his uncles Semen Lengvenaitis and Švitrigaila before accepting the Polish crown), while Oleśnicki's aim was to undermine Casimir's position in the Grand Duchy (and by extension, in Poland) by fostering a bothersome, but not too powerful rival for the monarch. $^{18}$

In short, the Grand Duchy was an impartible patrimony of the ruling dynasty and decisions on how that patrimony could be treated changed over the fifteenth century, in as far as we can tell, in a way similar to that in which general family inheritance law swayed between the old clan niedziat and new rules favouring individual lines. This process is connected with several factors but seems to be autochthonous rather than the result of definite influences from abroad.

16 J. Bardach. 'Trzecizna w Litewskim prawie majatkowym XV I XVI wieku', Cultus et cognition. Studia z dziejów średniowiecznej kultury (Warsaw, 1976), 81-95, esp. pp. 82-83.

${ }^{17}$ Archiwum Komisji prawnycznej, iii (Cracow, 1895), 79 from the Old Polish text in Kodeks Dzikowski; primogenitus - notes made by Długosz for St Casimir, as recorded in Ms. Czart. 1399, p.15, published in S.C. Rowell, 'Fifteenthcentury Poland-Lithuania in the light of an anonymous Cracow notebook' Quaestiones Medii Aevi Novae. 7 (2002).

18 S. C. Rowell, 'Casimir Jagiellończyk and the Polish gamble', Lithuanian Historical Studies 4 (1999), 20-21, 27, 37-38; Kopystiański, 'Książę Michał'. 
Poland and the Jagiellonian Inheritance From its very inception Jagiellonian policy towards the Polish Crown was aimed at preventing internecine strife among members of the Lithuanian ruling house in the Grand Duchy. This policy has a long history in Lithuania from at least the reign of Mindaugas. Poland was as much a political means for Jogaila as a simple end in itself. Poland provided money, prestige, and foreign policy aid but most of all it provided the Lithuanian princes with a source of asylum and a means of avoiding deadly struggles over the grand-ducal throne in a Grand Duchy close to civil war. In Poland possession of Lithuania guaranteed a monarch's election. The incorporation of Lithuania in the Polish crown agreed at Horodło was a clever dynastic political ploy by Jogaila and Vytautas to 'prove' the Christian nature of Lithuania by showing it to be a part of an undeniably ancient Christian polity, thereby undermining the Teutonic Order's claims before international tribunals that the Grand Duchy was a nest of pagans, heretics and schismatics. In addition it was, for Jogaila, a clever piece of domestic policy to strengthen his position as the naturalised, if not natural lord of Poland, the wearer of the Crown. If the Poles, especially in Małopolska, needed Lithuania, they had to have a Jagiellonian master. While Polish scholarship is right to stress the still not fully developed concept of corona regni and its separation from the person of the king, it tends to overlook the other aspect of this concept which does not hand over power to the other political agents within the kingdom without the king. W. Falkowski is surely right to note that "the middle ages did not know an autocratic rule held against the elite, or omitting the elite'. ${ }^{19}$ It is equally correct to assert that the Middle Ages did not know an oligarchic rule held against the king, or omitting the king (except in Switzerland or Italy). The crown is not an anti-royal concept per se. It represents the bond uniting the monarch and the Community of the Realm and as such can be used by either side to defend itself against the pretensions of the other. ${ }^{20}$ Further confusion is caused in the Polish case by a tendency (from the fifteenth century

${ }^{19}$ W. Falkowski, 'Regimen politicum et regale: The principle of government in 15th century Poland', Quaestiones Medii Aevi Novae, 1 (1996), 115.

${ }^{20} \mathrm{~W}$. Ullman, Principle of government and politics in the Middle Ages (London, 1961), 178-81; a survey of the early history of concepts of the 'crown' in Poland is given in J. Dąbrowski, Korona Królestwa Polskiego (Cracow, 1956). 
onwards) to identify the Crown with a geographical unit (the Kingdom of Poland) rather than a bond uniting the communities of the realms of Poland and Lithuania. ${ }^{21}$ When Jogaila refers to himself after his marriage and before his coronation as 'tutor et gubernator', he is not passing comment on his status within the kingdom of Poland in general terms, but offering a perfectly correct assessment of his temporary position before he became rex coronatus. ${ }^{22}$

When we look at the Jagiellonian 'acts of union', we are struck by the fact that they are almost all concluded in periods of particular significance for the ruling family. In 1401 when Jadwiga of Anjou was dead and Jogaila needed to reassert his and his heiress's position in both his realms Jogaila sought to obtain ratification hence the so-called 'Union of Vilnius-Radom' and his gamble with Vytautas (who was not, we would do well to keep in mind, condemned to die without male issue or before Jogaila). The Horodło Act of 1413 is more like a genuine 'interstate' agreement in so far as it is a pseudo-dynastic alliance between the nobility of Lithuania and Poland under the protection of Jogaila and Vytautas. The inclusion of a wide section of Polish and Lithuanian 'political society' in this agreement is probably why it is the 'union document' which is so frequently cited in later negotiations.

The other fourteenth- and fifteenth-century documents printed by Semkowicz and Kutrzeba as 'akta unji' are, in fact, simply acts of homage to Jogaila which recognise the latter's position as supreme duke-king. The Lithuanian civil wars of the 1430s are a family affair arguing over inheritance and as such they produce further 'acts of union' that confirm Jagiellonian rights. In these struggles the Lithuanian boiarate unavoidably gained opportunities to develop their political muscle. Jogaila emerges with his sons confirmed as heirs by both the other contenders (Žygimantas and Švitrigaila) and adolescent Lithuanian political society (the nobility) as a whole.

When Casimir was sent to Vilnius in 1440 and installed as grand duke he was not breaking the union but stretching it. He had been sent with the permission of Władysław his brother and the Polish nobility; when he was proclaimed grand duke by the Lithuanians his brother reverted to the 'supreme duke' tactic. When Władysław

${ }^{21}$ Falkowski, 'Regimen politicum', 117-18.

${ }^{22}$ Kodeks dyplomatyczny Wielkopolski, ed. I. Zakrzewski, III (Poznań, 1879), No. 1843, p. 573; commentary in Falkowski, 'Regimen politicum', 122. 
was slain at Varna, Casimir sought to make clear his position in both his inheritances. The 'act of union' was his coronation as king. No document was issued apart from a charter for Lithuania (now that his status was changing) and a practical agreement with the Poles - to allow him to travel he please and use the services of whomsoever he please irrespective of origin.

In 1453, it seems to me, ${ }^{23}$ a year after his most serious dynastic rivals, Mykolas Žygimantaitis and Švitrigaila had died, in the wake of serious outbreaks of violence in both the Grand Duchy and the Crown and on the eve of his personal union with Elisabeth of Austria, he issued a declaration which illustrated his view: that he had united both realms, that Lithuania could have the southern lands she disputed with Poland so long as she kept the status quo intact and that a general sejm should be held annually one year in Poland, the other in Lithuania. Around the time he made this declaration he confirmed Polish charters at long last after six years of dodging the issue and recognised his mother's rights to lands bestowed to her by Jogaila (thereby keeping the Lithuanian dynastic cat safely in the midst of the Cracow pigeons).

Poland should not be turned into a monolithic entity where Malopolskan noble ambitions are portrayed so strongly that we forget that a strong, largely Wielkopolskan monarchist viewpoint also existed. Szujski was careful to note the diversity of political opinion in Poland at the death of Casimir the Great (1370). His comments do not seem to be amiss when we looking at the Jagiellonian kingdom: 'W Wielkopolsce rozwiała sie grozna monarchji potega duchowieństwa ... Małopolska uchwyciła sie tronu, aby go zubozyc i z praw ogołocic'. ${ }^{24}$

The Jagiellonians together with their szlachta allies from Wielkopolska took pains to stress the hereditary nature of royal office. Jogaila took pains to stress his Piast inheritance through his wives, his election and his adoption. He repeatedly sought confirmation of his sons' inherited and natural right to the Polish Crown and both Polish and Lithuanian noblemen recognised this - even Bishop Zbigniew Oleśnicki could refer to Casimir as legitimate and

${ }^{23}$ Rowell, 'Casimir', 30-31; idem, '1446 and all that', Lietuva ir jos kaimynai. Nuo normanu iki Napoleono. Prof. Broniaus Dundulio atminimui, ed. E. Meilus et al. (Vilnius, 2001), 188-207.

24 J. Szujski, Dzieje Polski, I (Lwów, 1862), 293 cited in Kolankowski, 'Jagiellonowie i unja', 278. 
natural heir to his brother and father, when it suited him to speak in that way. ${ }^{25}$ Jogaila's sons were careful to stress their royal sonship in their titles, as indeed were Casimir's own son, the królewicy. Looking at fifteenth-century Lithuanian, Polish and Rus'ian documents and chronicles we are struck by repeated reference to Casimir in the period 1440-1447 as 'velikii kniaz Kazimir' korolevich' vsee Litovskoe zemli...', and to his sons in later periods as królewicy. ${ }^{26}$ There seems to have been constant stress on the Jagiellonian birth right to royal status. Looking at dictionaries of Old Polish and Old Russian, one is struck by the frequency of Jagiellonian use of this term, which means 'heir', while not abrogating the disputed Piast tradition of 'heres'. ${ }^{27}$

It is in the context of Malopolskan attempts to disinherit the Polish monarchy as a whole, not simply in the Jagiellonian case, that we note developments in attitudes towards Mazovia. The Mazovian dukes hover as a spectre over fifteenth-century Poland, but as such they seem to have been too frightening to the Malopolskan nobility for them to be permitted to become a real threat to the Jagiellonians. The point is a simple one and its rejoinder equally simple. If the House of Jogaila was so alien and potentially unacceptable, why did the Poles not elect Siemowit IV instead of Jogaila, Bolesław IV instead of Casimir (the actual ploy was rather uninspiring in 1446) or Janusz rather than John Albert or Alexander? The simple answer, removing particular circumstances, seems to be because they were Piasts. This is the direct explanation Długosz gives for the teasing rapprochements of 1446. They were Piasts and the Piasts were bad, it seems; even Casimir the Great is denounced as a murderer of priests and a philanderer. ${ }^{28}$ In other words they were quite strong - as around 1492 Kallimach warned John Albert to keep them at a distance, like his royal brother

25 1445-46: Długosz, V p. 3-4; CESXV I.1 No. 125, pp.140-44.

${ }^{26}$ LM5, 100, 131, 244 f. (here No. 128, p. 244) from 1440.

27 Slovar' drevnerusskogo iazyka (XI-XIV vv.), IV (izzhivati-moleniie), ed. R.I. Avanesov (Moscow, 1991), 268; Slovar' russkogo iazyka XI-XVII vv., vyp.VII (K-kraguiar') (Moscow, 1980), 337; Slownik staropolski, III.5 [18] (kołowrót-królewski), ed. S. Urbańczyk (Wrocław-Warsaw-Cracow, 1962), p. 399: królewicz, królewic, królowic, 'syn króla, regis filius', which by the sixteenth century had the normal meaning of 'heir to the crown' - Stownik polszczyzny XVI wieku, XI, ed. M.R. Mayenowa et al. (Wrocław-Warsaw-Cracow-Gdańsk, 1978), 222.

${ }^{28}$ Długosz, Historia V, 28. 
Sigismund ${ }^{29}$ - and their hereditary rights were even more difficult to deny than that of the parvenu Jagiellonians. They even had pretensions, in the person of Mykolas Žygimantaitis' widow, Catherine, to a large swathe of Lithuanian territory. The collector of information who produced the Czart. 1399 manuscript took pains to trace Mazovian genealogy back to the twelfth-century division of the kingdom and stress the feudal bonds between Mazovia and Bohemia that apparently tied all the heirs of Wanko, whose feudal tie to Bohemia is noted as having been transferred to Casimir the Great of Poland. Italian jurists are recorded as deciding that the Mazovian princes held their duchy 'in feodum paternum' binding not only the ruling duke but also his brothers. By comparison the position of Jogaila and his sons is much more impressive and 'natural', but even Jogaila's Piast marriages are stressed and hence the Mazovians are vassals to the Jagiellonian king. ${ }^{30}$ While certain Polish activists created the myth of Jadwiga of Anjou as 'the last of the Polish Piasts', other Polish antiquarians pass over the period between the death of Louis of Anjou and Jogaila's accession as a 'period of disturbance'. ${ }^{31}$

In 1526 Lithuanian councillors, seeking to gain royal status for the Grand Duchy in the face of Muscovite attempts at winning a crown from Rome, suggested that Sigismund the Elder retain Mazovia for himself, since it had been granted to his person rather than the Crown and use it together with the Grand Duchy to force the Polish nobility's hand in accepting Sigismund's son as next king. ${ }^{32}$

Mielnik - Une Affaire de Famille R. Trimonienè characterizes Jagiellonian politics as marked by 'apdairumas, patriarchališkumas, apgalvotas letumas' ${ }^{33}$ A characteristic missing from this list is a

29 'Rady Kallimacha', M. Gliszczeński, Rozmaitości naukowe i literackie, VII (Warsaw, 1860), 18-25.

${ }^{30}$ Cracow, Bibl. Czart. Ms. 1399, p. 5 (Casimir the Great and Siemowit), feodum: pp. 7, 9; Jagiellonians - pp. 16, 18.

31 Ms. Czart 1399, p. 15; Ms. Czart 1310, Codex Sedziwoj z Czechla, Zbieranka Skrócona (MPH III, p. 287) amidst Wielkopolskan records.

${ }^{32}$ Mazovia 'pripalo ne k' korune, ale k' parsune vashoe milosti' and should be kept together with the Grand Duchy and the Poles 'musiat' ego milost' [Sigismund Augustus] vziati za pana ... aby kniaz'stvo mazovetskoe ot' koruny sia ne otdalylo, azh' by sia ne zvuschilo z' velikim" kniaz'ctvom" litovskim"”, $A Z R$, ii (1506-1544) (St Petersburg, 1848), No. 144, p. 176 (1526, before June).

${ }^{33}$ R. R. Trimonienè, Lietuvos Didžioji Kunigaikštystè ir Vidurio Europa XVXVI a. sandūroje (Šiauliai, 1996), 52. 
willingness to gamble over the family inheritance. This is clear from Jogaila's concessions to Vytautas that were made without any certainty that Vytautas would die first and practically heirless; from Casimir's cat-and-mouse game with the Polish nobility over his acceptance of the Polish throne on his own hereditary terms and his further teasing over confirmation of Polish rights up to 1453 .

For almost fifty years Casimir successfully evaded demands that he subdivide his Lithuanian patrimony with his cousins or even his own sons. After his death two of his sons broke their father's rule in order perhaps to save his aim. Two rulers emerged in the Confederation. There are several reasons why the Union of the two domains became a matter of urgency in the 1490s. Both realms perceived themselves to be under threat from external enemies, the Turks, the Tatars and the Muscovites. These external threats may have helped to bring both sides to consider re-stating their relationship and the need to join forces against each side's enemies is stressed as a basic part of the relationship. However, this is surely more than a simple clarification that Alexander and John Albert will cooperate as two generations earlier Vytautas and Jogaila had worked together. Another aspect of this reassessment is dynastic: what to do after the death of the incumbent grand duke and the regnant king. It does not appear coincidental that calls to restate the Union agreement come as Alexander takes a wife and John Albert continues his attempts to woo a Habsburg bride and each plans his own line's future, including major crusades from the last such example of which the Jagiellonian king, Wladyslaw III, did not return alive.

Discussions over the state of the union began in earnest after Alexander's marriage to Elena Ivanovna of Moscow in early 1495. John Albert was particularly anxious to remove pressure on himself from the Władysław-Sigismund axis and find a solution to Sigismund's 'landless' state. It was envisaged creating a separate duchy of Kiev, perhaps along the lines suggested to and fiercely rejected by Casimir in the 1470s and 1480s. ${ }^{34}$ Discussions were held not only at the level of the Lithuanian and Polish councils but also among the family, including the Queen Mother, Elisabeth. This led inevitably to debates on the nature of the Jagiellonian realms. Alexander and his representatives stressed the indivisibility of the grand-ducal pan'stvo and so land could not be divided from Lithuania and granted to the

${ }^{34}$ LM5, pp. 100-111. 
'królewicz' Sigismund. ${ }^{35}$ The grand duchy never had "dvukh" panov"". ${ }^{36}$ Such a policy is said to go against the wishes of the Rada. The fear over Kiev was real - that it would be seized by the Turks or Muscovites, but division would surely run the risk of creating another Podolia (as was to be the case in 1566) or a more successful Švitrigaila. The Queen Mother and John Albert appear to have accepted this argument but required Alexander grant Sigismund compensation in the range of 5,000 zl. per annum for a couple of years until the king of Austria died and Sigismund could claim that throne through their mother. ${ }^{37}$ If Alexander were to refuse aid to Sigismund then Władysław would withdraw funding from their younger brother and all responsibility for the prince's osmotrenie would fall on the grand duke as holder of the family patrimony. ${ }^{38}$ The Polish council also viewed the Grand Duchy as the patrimonial home of an illustrious race of kings for other lands and required that Alexander granted Sigismund aid, since Casimir provided his other sons with kingdoms and his daughters with osmotrenie. ${ }^{39}$ Alexander's response was to deny that he had any povin'nosti or prymusheniia to help Sigismund other than the bond of blood between them - krovnym" oboviazaniem". ${ }^{40}$ As for the relationship between the two realms, that should be maintained according to the old agreements, as in Casimir's day, an equal fraternal bond without dishonour to either side. ${ }^{41}$ These points are reflected in the Latin treaty drafts sent from the Vilnius Sejm by the Lithuanian lords to their Polish counterparts in 1496 as published by Lewicki. ${ }^{42}$ These confirm Horodło and add that should the legitimus heres of Lithuania die (presumably without heirs of his body), a member of the preclarissima regali domo nostrorum dominorum from Poland should be elected in his place. Should the necessity arise in Poland, then a Jagiellonian from the Grand Duchy should be elected - here there is no mention of heres. ${ }^{43}$

35 AZR I No. 135, p. 156 = LM5 No. 54.1, April 9, 1496, Merkinè.

${ }^{36}$ Ibid., p. 135, part II = LM5 No. 54.2.

${ }^{37}$ Ibid., part IV, p. 158 = LM5 No. 55.

${ }^{38}$ Ibid., part VI, p. $161=$ LM5 No. 57.1.

${ }^{39}$ LM5 No. 57.3, pp. 107-108.

${ }^{40}$ LM5 No. 57.5, p. 110.

${ }^{41}$ LM 5 No. 57.6, 57.7 pp. 110-111.

${ }^{42}$ CESXV III, ed. A. Lewicki (Cracow, 1894), No. 422, pp. 437-39, No. 423, pp. $440-41$.

${ }^{43}$ Ibid., p. 440. 
In 1499 as Poland and Lithuania prepared for war against the Turk, a war from which return was by no means guaranteed, the Horodło agreement was renewed once more ${ }^{44}$. Although the dynasty is not mentioned in the final sections of the text, its rights have already been asserted in the confirmation of Horodło that forms the main body of the text and deals with the election of a king not following the death of the incumbent tout court but the death of the incumbent without heirs of the body ${ }^{45}$. The final paragraph of 1499 merely seeks to insist that the electorate meet jointly to choose new rulers and not act precipitately.

In fact it was in June 1501 that John Albert died unexpectedly. Up until then Alexander had been stressing the dynastically providential idea of incorporation; in summer 1501 he was promised the throne of Poland in return for incorporation. Alexander produced an agreement to win over the non-dynastic nobility in Poland: the act signed by both sides in Mielnik on October 23, 1501. This act's stipulations could not be removed from the circumstances in which they came to be formulated. It stressed the election of a king in Poland and passed over the possibility of a grand-ducal election in Lithuania, largely, I would argue, because Lithuania at that time already had a grand duke and he was seeking to become sole ruler of both realms. On October 30, 1501 Alexander was elected king in accordance with the old Horodło treaty, if we are to believe Wapowski's account, and Alexander's own proposals of June 1501 to the citizenry of Cracow. ${ }^{46}$ Incorporation or the creation of a new body politic containing both the (former) kingdom and the (former) grand duchy was not effected but it was not spoken of again in debates about union between 1501 and 1506. For Mielnik to be validated, reversales were promised by Alexander from the Lithuanian side, but these were never forthcoming. ${ }^{47}$ Whether this emerged

${ }^{44}$ We have in mind the fact that the rulers' uncle died on crusade against the Turk in 1444; settling family affairs before a military campaign is no unique step. Before leaving for war ('equitans ad bellum contra perfidos Moscovitas') against Moscow in 1500 the Vilnius boiar Grezegorz Jakieylowicz dispensed of family property - KDKDW No. 472, pp. 556-57.

${ }^{45}$ CESXV III Nos. 441-49, pp. 458-467: Grodno, February 1499, Cracow, May 1499 and Akta Unji Polski z Litwa 1385-1791 [AUPL], ed. S. Kutrzeba, W. Semkowicz (Cracow, 1932), No. 71-76, pp. 119-130.

${ }^{46}$ SRPol ii, pp. 45-46, 71; F. Piekosiński, 'Jeszcze słowo o ustawodwstwie wiślicko-piotrkowskim króla Kazimierza Wielkiego', Rozprawy Akademji Umiejętności, wydz. Hist.-filoz. XXXIII (ser. 2, vol. 8) (1896), 155-156.

47 AUPL, pp. 148-9, No. 83. 
from changes in Lithuanian noble policy or whether in fact the Mielnik agreement was all along a Jagiellonian sham to trick the Poles (with Lithuanian noble support) into accepting Alexander as king, or even if the grand duke-king realised that the Polish side thought he was disinheriting himself (if it really did think that) only after the agreement was sealed, does not really matter. There had been at least one other monarch-imposed 'union' agreement during Casimir's reign which also sank from sight unenforced - the 1446/ 1453 Act (recorded around this time in a manuscript notebook now preserved as Czartoryski manuscript 1399).

Mielnik refers directly to the union between Poland and Lithuania that was effected by Alexander's father Casimir, i.e., when a reigning grand duke was elected king. ${ }^{48}$ However, the treaty does not exclude Jagiellonian rights completely, pace Halecki and subsequent Polish and Lithuanian historians. Alexander speaks of his prolis and successores and he presumes himself to be the one ruler of both realms. The Mielnik agreement does not annul Jagiellonian rights to Lithuania. It takes them as read. It also presumes similar rights to the Polish Crown. Whether or not a twentieth-century historian considers that a sixteenth-century Polish nobleman would agree to such a presumption is not really relevant. Alexander bequeathed his patrimony in Poland and Lithuania to his brother Sigismund, ${ }^{49}$ whatever that might mean - landed estates or the Crown itself. When Halecki wrote of Sigismund's accession that 'o tem, aby Polacy uznali dziedziczne prawa Zygmunta do korony, oczywiście ne mogło byc mowy', we surely have a right to ask 'which Poles' 'obviously' did not recognise the królewicz's rights? ${ }^{50}$ One might even say that such a view of the Jagiellonian inheritance was deliberately omitted from the text ipsis verbis. In the debates between Władysław and Alexander following the latter's coronation in Poland, Alexander expressly states that the agreements of Jogaila and Vytautas (Horodło) that were confirmed in 1499 between John Albert and Alexander have not been contravened or derogated. ${ }^{51}$ While one might say that these debates are after the fact and self-defensive, and leap from one disputable

48 AUPL, p. 144.

49 Acta Tomiciana, I App. 6.

${ }^{50}$ Halecki, Dzieje Unji, ii, 37.

51 Akta Aleksandra [AA], ed. A. Papée (Cracow, 1927) Nr. 69, April 14, 1502. 
premise to another, can one really dismiss them as significantly and uniquely tendentious and invalid? All political discussion is essentially tendentious.

After Alexander's coronation Władysław complains that the Grand Duchy which is cum aliis fratribus suis communiter haereditarium ought to have been reallocated by brotherly consent after Alexander became king of Poland, and that Sigismund should be given his portio there. Poland is also referred to privately as solium regium paternum fraternumque, the same phrase as used during their father Casimir's ascent to the Polish throne. ${ }^{52}$ Alexander points out in response that he was elected in keeping with the agreements confirmed on May 6, 1499, whereby on the death of a king or grand duke without heirs, the living grand duke or king should be elected. ${ }^{53}$ No such stipulation was made in those terms in either 1499 or 1496, although the presumption of such a meaning is not surprising on the monarch's part. In fact it was stipulated that a Jagiellonian from either realm was to be elected, not necessarily a regnant member of the royal family. ${ }^{54}$

Władysław then moves on to the topic of primogeniture which he claims is common to all Christendom. The response of the Polish Rada to Władysław denies that ius primogeniturae 'in hoc Regno sibi locum non vendicat, quod pura electione in praeficiendo sibi rege semper usum est'. Here we have a statement which fits Piast and Jagiellonian successions and which denies not Jagiellonian heredity but primogeniture, a form of succession that was not valid in Lithuania either. ${ }^{55}$ The Polish nobility stress that they did nothing new in the past election, let alone anything that would harm the rights of Władysław and Sigismund quantum ... ad ducatum Lithuaniae et ius haereditarium. They claim that heredity was removed in Lithuania by the old acts (i.e., Horodło) and that the principle of election was introduced as events after Vytautas' death are alleged (falsely) to show. ${ }^{56}$ This is not strictly true.

Władysław claims that the Lithuanian party broke Horodło by electing Alexander after Casimir's death without inviting the king

52 AA, No. 45, pp. 44-45.

53 AA, No. 69, p. 76.

${ }^{54}$ AUPL, Nos 71-76, pp. 119-130; CESXV III Nos 421-423, pp. 436-441, Nos 442-449, pp. 459-467.

${ }^{55} \mathrm{Cf}$. AA, p. 84. Władysław's views on primogeniture are coloured by his own status (or rather, non-status) as Casimir's first-born son.

${ }^{56}$ AA, No. 69, p. 78. 
and lords of Poland to take part (here the point is a little strained, given that the king, the same Casimir, was dead too!). Thus the agreement was broken and has to be renewed with Władysław and Sigismund taking part too. Władysław seems to imply that the grand duke of Lithuania should not also be king of Poland and that when there is no grand duke, the king and the Poles should elect a separate grand duke, in this case Sigismund. ${ }^{57}$

For the sake of stressing his own and Sigismund's inheritance Władysław views the Jogaila-Vytautas duet as the ideal (as Oleśniski professedly did), rather than a compromise en route to one ruler thereby rejecting Casimir's own policy of keeping the Grand Duchy and the Kingdom in one pair of hands. The 1496 proposals also foresee union under two rulers, and in case of death without heirs, that a Jagiellonian from Poland be elected grand duke. Two strands of thought at least are intertwined in this debate: that the Jagiellonians enjoy hereditary rights to both realms and that both should be united, especially by the person already in control of Lithuania, which is used to blackmail the Polish nobility.

The Lithuanian gentry was never against a union with Poland. It simply preferred to have its own Jagiellonian line, and did not object to defunct Polish Jagiellonian's being replaced by a Jagiellonian from the Grand Duchy, but not by the grand duke himself. ${ }^{58}$

When Alexander died in Vilnius in 1506, his brother was hastily elected grand duke, in theory providing Lithuania and the dynasty with the upper hand over the Polish council. The Polish side had little real choice but to elect the królewicz to whom Władysław surrendered his rights to Lithuania, Alexandro defuncto, thereby strengthening Sigismund's position as heir to both realms. The Jagiellonian succession continued de facto and the Union survived. It seems pointlessly pedantic to view Sigismund's election as a breach of any agreement. The Poles could have elected Władysław of Hungary-Bohemia or Janusz of Mazovia, had they so wished, but in actual fact they made the only free choice that was open to them - Wapowski points out the impracticality of electing Władysław as ruler of three realms in 1501, to say nothing of four in 1506 and the unsuccessful precedent of a Polish-Hungarian union under Louis of Anjou (1370-82). ${ }^{59}$ We have already noted the disdain (or dread) in which the Mazovian Piasts were held in Małopolska.

57 AA, p. 82.

${ }^{58}$ CESXV III, p. 439.

59 Scriptores rerum polonicarum ii, 45-46, 71. 
In conclusion we can say in general of the 1501 treaty that details of the Mielnik agreement fit the political debates held in Poland and Lithuania in the second half of the fifteenth century. The prominent position played by the Lithuanian nobility reflects developments in the Grand Duchy's political nation during the second half of the fifteenth century. It fits in part the programmes laid down by Jan Ostrorog and Filip Kallimach who were close to the Jagiellonian court of Casimir IV and his sons. Ostrorog advocated a strong monarchy, proposing that a sejm (conventio generalis) be held once a year, that there be a uniform legal system in the kingdom with a written law. ${ }^{60}$ Kallimach, who was responsible for educating two of the królewiczi offered sensible practical advice to John Albert to obtain and maintain absolutum dominium with unus rex, una lex. Measures included careful exploitation of the senate and the royal family. ${ }^{61}$ It even fits the stand taken by the author of $D e$ institutione pueri Regis. ${ }^{62}$ In Mielnik too there is heavy stress on the powerful position of the king, on the unity of written legal codes, on equality of representation between the Kingdom and the Grand Duchy (stressed in 1446/53) and a common currency. Alexander severely hampered his chances of introducing such reforms by the mere fact that he took up residence in Lithuania, thereby granting the Polish nobility a chance to recover from the pressure exerted on them by Casimir and John Albert.

This agreement continues the line taken at Horodło to form a united community of the realms with one ruler under the Crown. It is a stage in Malopolskan noble thinking on the rights of the szlachta to take part in government and it is yet another example of Jagiellonian bartering with their inheritance to strengthen their position in Poland. In the addition of the reversales clause it fits the 1453 model of a wide-ranging agreement with possible dangerous

60 Jan Ostroróg, 'Memorjał dla sejmu walnego o urzadzeniu królestwa (ok. 1476)', Humanizm i reformacja w Polsce. Wybór źródet dla cwiczeń uniwersyteckich, ed. J. Chrzanowski and S. Kot (Lwów-Warsaw-Cracow, 1927), 61-72, esp. 68-9.

61 'Rady Kallimacha', M. Gliszczeński, Rozmaitości naukowe i literackie, VII (Warsaw, 1860), 18-25. In general see K. Baczkowski, Rady Kallimacha (Cracow, 1989).

${ }^{62}$ A. Przezdziecki, 'O królowej Elżbiecie żonie Kazimierza Jagiellończyka i rękopisie pod jej imieniem "o wychowaniu królewskiego dziecka”, Biblioteka Warszawska xlv (1852), t.1, pp. 524-30. 
overtones for the Jagiellonians (or the Polish szlachta) and a builtin self-destruct clause. In the case of 1453 squabbles over Volyn' and Podolia continued, thereby annulling the agreement and returning it to the status quo ante, and in 1501 the failure on the part of the Lithuanian nobility to provide reversales reduced the effectiveness of Mielnik. Quite why this should be regarded as purely Lithuanian noble opposition to the agreement and its guarantor the king grand duke, is unclear. The reversal clause was a novelty in Union acts and was introduced not into the text issued by the Lithuanian nobility but into a further clarification issued by Alexander. The Lithuanian negotiators had been given plenipotential powers to treat with their Polish counterparts. Given the tendency to bluff and gamble inherent in much of Jagiellonian politics, one might suspect that the agreement as a whole was an exercise in election propaganda that was less important (but not unimportant) after Alexander was crowned king of Poland. Interest in the 1446/53 agreement was shown during or slightly after Alexander's reign, as is indicated by its survival in two manuscripts, one of unknown provenance but of clearly pro-regalian leanings that is held in the Czartoryski Library in Cracow, the other in Acta episcopalia posnaniensia, I: 1439-57. The Polish side at Mielnik was represented by Bishop Jan Lubrański of Poznań, who is mentioned in another text preserved in Ms. Czart. 1399.

There are other similarities between Mielnik and the text which Casimir issued to pacify Lithuanian demands over Podolia and Volyn' on the eve of his marriage to Elisabeth of Austria. Both documents stress the equal nature of the relationship between the two realms and a system of alternate sejms in Poland and Lithuania to discuss issues affecting the bonum commune. The arengae of both documents note how concordia ... res parvae crescunt, dicordia vero et maxime dilabuntur. It is a commonplace remark, but other phrases could have been used and were not.

In sum, in Poland-Lithuania in the late fifteenth and early sixteenth centuries there were at least three reasonably well-balanced political forces, viz. the Polish nobility, the Lithuanian nobility and the House of Jogaila to each of whom for various reasons the Union was a necessary and desirable political conjuncture and we should not tidy up the dynamic 'on the hoof' politics of that age for some document-bound order that creates its own scholarly chaos. 
Author Details

S. C. Rowell, м.A., PH.D. (Cantab), Lithuanian Institute of History, Kražių 5, LT-2001, Vilnius, Lithuania

DINASTU BLEFAI? KELIAS IKI MELNIKO, 1385-1501 M.

\section{Santrauka}

\section{S. C. ROWELL}

Autorius apžvelgia ilgalaikę $1501 \mathrm{~m}$. Melnike paskelbtos LDK-Lenkijos Karūnos unijinès sutarties raidą per lietuvių-lenkų santykių prizmę ir unijos aktų raidos longue durée nuo pat 1385-1386 m. Jis pabrèžia būtinumą rimtai vertinti dinastinę Jogailos bei jo sūnaus Kazimiero teisę i abiejų valstybių sostus, suprantamus kaip dalijamą šeimos turtą, didesnį dèmesị kreipdamas i XV a. įvykusius šeimos turto bei paveldèjimo teisès pakitimus tiek Lenkijoje, tiek LDK. Aptariami galimi tekstiniai ryšiai tarp vieno apie 1453 m. sukurto ,unijos“ akto bei Melnike paskelbto susitarimo.

Received 13 April 2001 